\title{
EFEKTIVITAS PEMBERIAN SILASE LIMBAH IKAN UNTUK MENINGKATKAN PANJANG TULANG FEMUR, TIBIA DAN METATARSUS, PADA BEBEK PEDAGING
}

\author{
Mei Sulistiyoningsih ${ }^{1}$, Reni Rakhmawati ${ }^{2}$ \\ ${ }^{1,2}$ Universitas PGRI Semarang
}

\begin{tabular}{l}
\hline Keyword \\
\hline $\begin{array}{l}\text { Duck meat, Fish waste } \\
\text { silage, Bone length }\end{array}$ \\
\\
\hline Corresponding Author \\
\hline rahmamashuri@yahoo.c \\
o.id
\end{tabular}

Abstrac

The purpose of this study was to determine the effectiveness of silage of fish waste in the diet on the length of the leg bones, especially the femur, tibia and metatarsus in broiler ducks. The subjects used in this study were 100 DOD (Day Old Duck). The design used was Completely Randomized Design (CRD). The research material consisted of 3 treatments with 4 replications. The treatments in this study were PO (commercial ration)/control, $P 1$ (commercial ration $+5 \%$ fish waste silage), and P2 (commercial ration $+10 \%$ fish waste silage). The research variables measured were the femur, tibia and metatarsus in ducks using a caliper. The control variables were health management, type of duck, age of duck, and cage. The data obtained were then analyzed using variance (ANOVA) with a level of 5\%. The results showed that there was no significant effect $(P>0.05)$ on the length of the femur, tibia and metatarsus in broiler ducks.

\begin{abstract}
Abstrak
Tujuan penelitian ini adalah untuk mengetahui keefektifan pemberian silase limbah ikan dalam ransum terhadap panjang tulang tungkai, khususnya pada tulang femur, tibia dan metatarsus pada bebek pedaging. Subjek yang digunakan dalam penelitian ini adalah 100 ekor DOD (Day Old Duck). Rancangan yang di gunakan adalah Rancangan Acak Lengkap (RAL). Materi penelitian terdiri dari 3 perlakuan dengan 4 ulangan. Perlakuan dalam penelitian ini adalah P0 (Ransum komersial)/Kontrol, P1(Ransum komersial $+5 \%$ silase limbah ikan), dan P2 (Ransum komersial $+10 \%$ silase limbah ikan). Variable penelitian yang di ukur adalah tulang femur, tibia dan metatarsus pada bebek dengan menggunakan jangka sorong. Variabel kendalinya adalah manajemen kesehatan, jenis bebek, umur bebek, dan perkandangan. Data yang diperoleh selanjutnya dianalisis menggunakan sidik ragam (ANOVA) dengan taraf $5 \%$. Hasil penelitian menunjukkan tidak ada pengaruh nyata $(\mathrm{P}$ $>0,05)$ terhadap panjang tulang femur, tibia dan metatarsus pada bebek pedaging.
\end{abstract}

Kata Kunci: Bebek Pedaging, Silase Limbah Ikan, Panjang Tulang

PENDAHULUAN 
Kebutuhan masyarakat akan sumber gizi yang berasal dari hewani semakin meningkat. Tingkat konsumsi daging yang meningkat memicu para peternak berupaya untuk memenuhi kebutuhan masyarakat dengan meningkatkan produktivitas ternak unggas menggunakan teknis yang praktis dan instan seperti penggunaan obat-obat kimia. Penggunaan obat-obat kimia dapat meninggalkan residu pada tubuh ternak. Residu antibiotik dapat menyebabkan resistensi bakteri sehingga membahayakan ternak dan konsumen (Masrianto et. al., 2013).

Kebutuhan daging yang berkualitas baik sangat dibutuhkan oleh masyarakat. Tindakan yang perlu dilakukan untuk mendapatkan daging berkualitas dan tulang yang panjang serta sehat dengan memperhatikan manajemen pemeliharaan dan pemberian pakan yang sesuai. Pakan merupakan salah satu faktor penting yang mendukung keberhasilan dalam usaha peternakan. Penggunaan bahan pakan lokal sebagai pakan tambahan (feed additive) dapat menekan biaya produksi yang berlebih. Bahan pakan yang digunakan harus memiliki kandungan gizi yang dapat meningkatkan pertumbuhan dan perkembangan ternak. Penggunaan pakan silase organik sebagai pakan tambahan yang akan dicampurkan dengan pakan komersial diharapkan dapat memperbaiki performans kualitas daging bebek. Saat ini masyarakat lebih memilih produk yang bersifat natural atau yang tidak banyak mengadung bahan kimia. Penggunaan pakan silase yang berasal dari limbah ikan dapat dikembangkan dalam budidaya peternakan.

Pemanfaatan limbah perikanan menjadi bahan pakan dapat memberikan arti penting bagi produksi peternakan, salah satu diantaranya yang memungkinkan untuk dimanfaatkan sebagai bahan pakan alternatif adalah limbah ikan. Limbah ikan yang terdiri atas kepala, isi perut, daging, dan tulang ikan bila diberikan secara langsung dapat menimbulkan efek negatif karena cepat rusak dan menjadi busuk, sehingga perlu dilakukan pengolahan terlebih dahulu. Salah satu usaha untuk pengolahan limbah ikan yaitu melalui proses pembuatan silase ikan, baik secara kimiawi maupun secara biologis (Abun, 2004).

Silase adalah bahan pakan atau ransum berkadar air tinggi (40 - 70\%) yang diawetkan dalam kondisi an-aerob selama waktu tertentu. Silase dikatakan baik jika mempunyai $\mathrm{pH} 3-4$, bau asam (didominasi oleh asam laktat) tidak berjamur mempunyai warna seperti atau mendekati warna bahan pakan atau ransum sebelum difermentasi, mengandung bakteri asam laktat lebih dari 106 dan mempunyai nilai gizi yang hampir sama dengan bahan asalnya karena kehilangan bahan kering selama proses fermentasi sangat sedikit. Silase yang baik dapat bertahan lebih dari satu tahun bila disimpan dalam kondisi an-aerob tanpa secara nyata menurunkan nilai gizinya, dengan adanya pakan silase limbah ikan yang awet maka lebih memudahkan kita dalam waktu penyimpanan pakan silase limbah ikan terhadap bebek karna silase limbah ikan berbeda dengan pakan yang lain, yang cepat membusuk, tidak tahan lama dalam penyimpanan dan pakan limbah silase limbah ikan ini juga tidak mengurangi nilai gizi pada pakan silase limbah ikan tersebut.

Limbah ikan yang mengalami proses pengolahan (silase ikan) selain mempunyai nilai gizi yang tinggi juga dapat memberikan rasa dan aroma yang khas, mempunyai daya cerna tinggi serta kandungan asam amino yang tersedia menjadi lebih baik. Keunggulan lain dari silase ikan, pengolahannya tidak menimbulkan pencemaran lingkungan (Abun, 2004).

Penelitian silase limbah ikan ini akan menggunakan ransum pakan, dengan komposisi bekatul, konsentrat dan limbah ikan. Penambahan limbah ikan diharapkan dapat meningkatkan panjang tulang dan efisiensi pakan selama periode waktu penelitian. Pemanfaatan limbah ikan dalam ransum unggas diharapkan dapat mengurangi penggunaan pakan komersial yang hingga kini masih bernilai input relatif tinggi. 
Menurut Bevelander (1974), bahwa proses perkembangan tulang diawali dengan pembentukan tulang yang merupakan peningkatan produksi jumlah substansi dasar sel. Pada waktu yang sama ukuran sel meningkat, diperkirakan sebagai suatu bentuk polyhedral, selanjutnya melalui jumlah prosesus sel-sel yang berdekatan saling dihubungkan. Pada tahap ini sel-sel tersebut diketahui sebagai osteoblast, dan osteoblast menyusun permukaan lapisan tulang. Peningkatan ketebalan tulang terjadi melalui penambahan lapisan dari matrik yang dihasilkan oleh aktifitas osteoblastic. Menurut Wilson et al. (1991), bahwa jaringan tulang tumbuh dan berkembang dipengaruhi oleh faktor genetik, pakan dan fungsi hormonal yang mempengaruhi laju pertumbuhan, bentuk tulang, serta ukuran dari tulang.

Pemeliharaan bebek perlu menggunakan sistem pemeliharaan intensif, dimana proses pemeliharaan ternak dilakukan didalam kandang dari awal hingga panen dengan menggunakan manajemen pemeliharaan yang lebih baik, seperti pemberian pakan silase limbah ikan atau nutrisi yang baik, sistem pemeliharaan yang baik, kondisi lingkungan dan sistem perkandangan yang baik, serta pengawasan kesehatan yang baik, hingga dapat menghasilkan panen dan ukuran panjang tulang yang lebih optimal. Wahju (2004), meningkatkan konsumsi ransum akan memberikan kesempatan kepada tubuh untuk mencerna lebih banyak makanan sehingga kebutuhan protein untuk pertumbuhan tulang terpenuhi jika pemberian pakan silase limbah ikannya banyak maka tubuh bebek tersebut juga akan semakin besar dan tulang bebekpun juga bisa semakin panjang, sedikit atau banyaknya pemberian pakan silase limbah ikan itu juga berpengaruh terhadap panjang tulang pada bebek pedaging.

\section{METODE}

Penelitian ini menggunakan Rancangan Acak Lengkap (RAL). Sampel penelitian ini adalah DOD (Day Old Duck), bebek pedaging umur sehari unsex, BB $\pm 65 \mathrm{~g}$, dengan 3 perlakuan dengan 4 ulangan. Perlakuan yang diterapkan yaitu P0 (Ransum komersial)/Kontrol, P1(Ransum komersial $+5 \%$ silase limbah ikan), dan P2 (Ransum komersial $+10 \%$ silase limbah ikan). Variabel dependen terdiri dari tulang femur, tibia dan metatarsus pada bebek. Variabel kendalinya adalah, manajemen kesehatan, jenis bebek, umur bebek, dan perkandangan. Data yang diperoleh dianalisis dengan Analisis of Variance (ANAVA), dilanjutkan dengan Uji Jarak Ganda Duncan (UJGD).

\section{HASIL}

Data hasil penelitian pada peningkatan kualitas bebek pedaging terhadap panjang tulang dengan penambahan silase limbah ikan sebagai berikut :

a. Data Panjang Tulang Femur

Tabel 1. Panjang Tulang Femur Bebek Pedaging dengan Penambahan Silase Limbah Ikan

\begin{tabular}{|c|c|c|c|c|c|c|}
\hline \multirow[t]{2}{*}{ Perlakuan } & \multicolumn{4}{|c|}{ Ulangan Ke } & \multirow{2}{*}{$\begin{array}{l}\text { Jumlah } \\
\text { Perlakuan (T) }\end{array}$} & \multirow{2}{*}{$\begin{array}{c}\text { Rataan } \\
\text { Perlakuan }\end{array}$} \\
\hline & 1 & 2 & 3 & 4 & & \\
\hline $\mathrm{P} 0$ & $5,9 \mathrm{~cm}$ & $6,0 \mathrm{~cm}$ & $5,7 \mathrm{~cm}$ & $6,1 \mathrm{~cm}$ & $23,7 \mathrm{~cm}$ & $5,925^{\mathrm{a}} \mathrm{cm}$ \\
\hline $\mathrm{P} 1$ & $6,2 \mathrm{~cm}$ & $6,2 \mathrm{~cm}$ & $5,8 \mathrm{~cm}$ & $5,9 \mathrm{~cm}$ & $24,1 \mathrm{~cm}$ & $6,025^{\mathrm{a}} \mathrm{cm}$ \\
\hline $\mathrm{P} 2$ & $6,3 \mathrm{~cm}$ & $5,7 \mathrm{~cm}$ & $6,0 \mathrm{~cm}$ & $6,3 \mathrm{~cm}$ & $24,3 \mathrm{~cm}$ & $6,075^{\mathrm{a}} \mathrm{cm}$ \\
\hline Jumlah Ulangan & $18,4 \mathrm{~cm}$ & $17,9 \mathrm{~cm}$ & $17,5 \mathrm{~cm}$ & $18,3 \mathrm{~cm}$ & $72,1 \mathrm{~cm}$ & $18,025 \mathrm{~cm}$ \\
\hline Rataan Ulangan & $6,13 \mathrm{~cm}$ & $5,96 \mathrm{~cm}$ & $5,83 \mathrm{~cm}$ & $6,1 \mathrm{~cm}$ & $24,03 \mathrm{~cm}$ & $6,008 \mathrm{~cm}$ \\
\hline
\end{tabular}

Keterangan : Nilai dengan huruf superscript yang berbeda menunjukan hasil yang berbeda nyata. Tabel 1. Menunjukan bahwa pada kolom yang sama dengan baris berbeda menunjukan hasil yang berbeda nyata.

P0 : Ransum komersial (kontrol)

P1 : Ransum komersial $+5 \%$ silase limbah ikan 
$\mathrm{P} 2$ : Ransum komersial $+10 \%$ silase limbah ikan

b. Data Panjang Tulang Tibia

Tabel 2. Panjang Tulang Tibia Bebek Pedaging dengan Penambahan Silase Limbahn Ikan

\begin{tabular}{|c|c|c|c|c|c|c|}
\hline \multirow[t]{2}{*}{ Perlakuan } & \multicolumn{4}{|c|}{ Ulangan Ke } & \multirow{2}{*}{$\begin{array}{c}\text { Jumblah } \\
\text { Perlakuan } \\
\text { (T) } \\
\end{array}$} & \multirow{2}{*}{$\begin{array}{c}\text { Rataan } \\
\text { Perlakuan }\end{array}$} \\
\hline & 1 & 2 & 3 & 4 & & \\
\hline P0 & $10,6 \mathrm{~cm}$ & $10,7 \mathrm{~cm}$ & $10,5 \mathrm{~cm}$ & $10,6 \mathrm{~cm}$ & $42,4 \mathrm{~cm}$ & $10,6^{\mathrm{a}} \mathrm{cm}$ \\
\hline $\mathrm{P} 1$ & $11,1 \mathrm{~cm}$ & $10,6 \mathrm{~cm}$ & $10,4 \mathrm{~cm}$ & $10,8 \mathrm{~cm}$ & $42,9 \mathrm{~cm}$ & $10,725^{a} \mathrm{~cm}$ \\
\hline $\mathrm{P} 2$ & $10,8 \mathrm{~cm}$ & $9,9 \mathrm{~cm}$ & $10,7 \mathrm{~cm}$ & $10,9 \mathrm{~cm}$ & $42,3 \mathrm{~cm}$ & $10,575^{a} \mathrm{~cm}$ \\
\hline $\begin{array}{l}\text { Jumlah } \\
\text { Ulangan }\end{array}$ & $32,5 \mathrm{~cm}$ & $31,2 \mathrm{~cm}$ & $31,6 \mathrm{~cm}$ & $32,3 \mathrm{~cm}$ & $127,6 \mathrm{~cm}$ & $31,9 \mathrm{~cm}$ \\
\hline $\begin{array}{l}\text { Rataan } \\
\text { Ulangan }\end{array}$ & $10,83 \mathrm{~cm}$ & $10,4 \mathrm{~cm}$ & $10,53 \mathrm{~cm}$ & $10,76 \mathrm{~cm}$ & $42,53 \mathrm{~cm}$ & $10,63 \mathrm{~cm}$ \\
\hline
\end{tabular}

Keterangan : Nilai dengan huruf superscript yang berbeda menunjukan hasil yang berbeda nyata. Tabel 2. Menunjukan bahwa pada kolom yang sama dengan baris berbeda menunjukan hasil yang berbeda nyata.

P0 : Ransum komersial (kontrol)

$\mathrm{P} 1$ : Ransum komersial $+5 \%$ silase limbah ikan

P2 : Ransum komersial $+10 \%$ silase limbah ikan

c. Data Panjang Tulang Metatarsus

Tabel 3. Panjang Tulang Metatarsus Bebek Pedaging dengan Penambahan Silase Limbah Ikan

\begin{tabular}{|c|c|c|c|c|c|c|}
\hline \multirow[t]{2}{*}{ Perlakuan } & \multicolumn{4}{|c|}{ Ulangan Ke } & \multirow{2}{*}{$\begin{array}{c}\text { Jumlah } \\
\text { Perlakuan } \\
\text { (T) }\end{array}$} & \multirow{2}{*}{$\begin{array}{c}\text { Rataan } \\
\text { Perlakuan }\end{array}$} \\
\hline & 1 & 2 & 3 & 4 & & \\
\hline P0 & $6,1 \mathrm{~cm}$ & $6,1 \mathrm{~cm}$ & $5,8 \mathrm{~cm}$ & $6,0 \mathrm{~cm}$ & $24 \mathrm{~cm}$ & $6^{\mathrm{a}} \mathrm{cm}$ \\
\hline $\mathrm{P} 1$ & $6,3 \mathrm{~cm}$ & $6,2 \mathrm{~cm}$ & $5,9 \mathrm{~cm}$ & $5 \mathrm{~cm}$ & $23,4 \mathrm{~cm}$ & $5,85^{a} \mathrm{~cm}$ \\
\hline $\mathrm{P} 2$ & $6,4 \mathrm{~cm}$ & $5,9 \mathrm{~cm}$ & $5,9 \mathrm{~cm}$ & $6,2 \mathrm{~cm}$ & $24,4 \mathrm{~cm}$ & $6,1^{\mathrm{a}} \mathrm{cm}$ \\
\hline $\begin{array}{l}\text { Jumlah } \\
\text { Ulangan }\end{array}$ & $18,8 \mathrm{~cm}$ & $18,2 \mathrm{~cm}$ & $17,6 \mathrm{~cm}$ & $17,2 \mathrm{~cm}$ & $71,8 \mathrm{~cm}$ & $17,95 \mathrm{~cm}$ \\
\hline $\begin{array}{l}\text { Rataan } \\
\text { Ulangan }\end{array}$ & $6,26 \mathrm{~cm}$ & $6,06 \mathrm{~cm}$ & $5,86 \mathrm{~cm}$ & $5,73 \mathrm{~cm}$ & $23,93 \mathrm{~cm}$ & $5,98 \mathrm{~cm}$ \\
\hline
\end{tabular}

Keterangan : Nilai dengan huruf superscript yang berbeda menunjukan hasil yang berbeda nyata. Tabel 3. Menunjukan bahwa pada kolom yang sama dengan baris berbeda menunjukan hasil yang berbeda nyata.

P0 : Ransum komersial (kontrol)

$\mathrm{P} 1$ : Ransum komersial $+5 \%$ silase limbah ikan

$\mathrm{P} 2$ : Ransum komersial $+10 \%$ silase limbah ikan

\section{PEMBAHASAN}

Hasil penelitian terhadap panjang tulang femur diketahui bahwa pertumbuhan tulang femur tertinggi terdapat pada perlakuan 3 yaitu P2 dengan hasil rataan perlakuan $6,075 \mathrm{~cm}$ yaitu pada Ransum komersial $+10 \%$ silase limbah ikan dan pertumbuhan tulang femur paling rendah terjadi pada pada perlakuan 1 yaitu P0 dengan hasil rataan perlakuan 5,925 $\mathrm{cm}$ yaitu pada ransum komersial kontrol berdasarkan perhitungan sidik ragam ketiga perlakuan terhadap panjang tulang femur diketahui bahwa tidak berbeda nyata $>0,05 \%$, yang menyatakan bahwa Ho diterima yaitu tidak ada efektivitas ketiga perlakuan terhadap panjang tulang femur. 
Faktor penyebab tidak adanya efektivitas ketiga perlakuan terhadap panjang tulang femur diantaranya adalah hasil panjang tulang perlakuan hampir sama dengan panjang tulang tungkai normal. Berdasarkan hasil rerata tersebut diketahui tidak berbeda jauh dengan hasil panjang tulang femur dengan perlakuan yaitu, panjang tulang femur tertinggi terdapat perlakuan 3 pada $\mathrm{P} 2$ dengan rerata $6,075 \mathrm{~cm}$ dan hasil reratapanjang tulang femur terendah terjadi pada perlakuan P0 yaitu dengan panjang $5,925 \mathrm{~cm}$.

Diduga dalam kondisi normal atau tanpa perlakuan ransum komersial sudah mampu memenuhi kriteria untuk proses pertumbuhan tulang femur, yaitu dengan kandungan kalsium dan fosfor dalam ransum yang digunakan dalam penelitian.

Faktor penyebab perbedaan panjang tulang femur meliputi sifat fisiogi tulang femur, ransum yang berpengaruh terhadap nutrisi yang dibutuhkan pada bebek berpengaruh terhadap hormonal bebek, pernyataan tersebut didukung penelitian-penelitian sebelumnya yaitu menurut Rose (1997), faktor-faktor yang mempengaruhi pertumbuhan tulang meliputi faktor endogenous (faktor yang dipengaruhi oleh hormone) dan exogeneous (faktor yang dipengaruhi oleh pakan) yang meliputi faktor nutrisi yaitu, protein vitamin, mineral dan kalsium.

Tulang femur merupakan organ eksterior tubuh yang berfungsi menompang tubuh serta menjaga keseimbangan yang mempunyai kecepatan mineralisasi tulang lebih lambat dibandingkan dengan tulang tibia maupun tulang metatarsus dan hal ini diduga bahwa tulang femur merupakan rangkaian penyebab abnormalitas perkembangan panjang tulang. Tulang femur lebih sensitif terhadap perubahan ransum dibandingkan tulang tibia (Hastuti et al., 2013). Silase limbah ikan dapat bertahan dalam waktu yang lebih lama dibandingkan dengan bahan pakan yang diolah dengan teknologi pengeringan, silase mengandung asam organik dan bakteri asam laktat yang sangat berguna dalam meningkatkan efisiensi penggunaan pakan. Beberapa negara maju asam organik telah diklaim sebagai bahan pemacu pertumbuhan (growth promoter) disamping sebagai bahan pengawet bahan pakan dan pangan, sedangkan bakteri asam laktat telah umum diketahui sebagai probiotik. Pemberian pakan silase pada ternak tidak memerlukan lagi penambahan bakteri asam laktat (probiotik) dan asam organik (pemacu pertumbuhan), dengan perkataan lain pemberian pakan silase pada ternak akan mengurangi biaya pakan dan sekaligus juga dapat menurunkan impor BAL dan asam organik dalam jangka panjang. Ternak yang diberi silase akan memperoleh air alami (air dalam bahan pakan), sehingga kebutuhan air dari luar menjadi lebih sedikit.

Kalsium dan fosfor diperlukan untuk memaksimalkan puncak masa tulang dan mempertahakan densitas tulang yang normal (Rizkuna et. al., 2014). Kalsium (Ca) merupakan mineral esensial terbanyak dalam tubuh, lebih dari $90 \%$ kalsium dalam tubuh terdapat dalam tulang. Kalsium berperan penting dalam sejumlah aktivitas enzim pada penyaluran atau implus saraf dan kontraksi otot (Setiawan, 2016).

Hasil penelitian terhadap panjang tulang tibia diketahui bahwa pertumbuhan tulang tibia tertinggi terdapat pada perlakuan 2 yaitu P1 dengan hasil rataan perlakuan $10,725 \mathrm{~cm}$ yaitu pada ransum komersial $+5 \%$ silase limbah ikan dan dan pertumbuhan tulang tibia paling rendah terjadi pada pada perlakuan 1 yaitu $\mathrm{P} 0$ dengan hasil rataan perlakuan 10,6 cm yaitu pada ransum komersial kontrol berdasarkan perhitungan sidik ragam ketiga perlakuan terhadap panjang tulang tibia diketahui bahwa tidak berbeda nyata $>0,05 \%$ yang menyatakan bahwa Ho diterima yaitu tidak ada efektivitas ketiga perlakuan terhadap panjang tulang tibia.

Faktor penyebab perbedaan panjang tulang femur meliputi sifat fisiogi tulang femur, ransum yang berpengaruh terhadap nutrisi yang dibutuhkan pada bebek berpengaruh terhadap hormonal bebek, pernyataan tersebut didukung penelitian-penelitian sebelumnya yaitu menurut Rose (1997), faktor-faktor yang mempengaruhi pertumbuhan tulang meliputi factor endogenous (faktor yang dipengaruhi oleh hormone) dan exogeneous (faktor yang 
dipengaruhi oleh pakan) yang meliputi factor nutrisi yaitu, protein vitamin, mineral dan kalsium.

Sifat fisiologi tulang tibia adalah tulang yang memiliki korelasi positif dengan bobot badan, bobot badang menyumbang 90\%-98\% variabilitas ukuran panjang tulang tibia. Tulang tibia memiliki kecepatan mineralisasi lebih baik dibanding meneralisasi tulang femur (Sartika, 2000).

Pertumbuhan tulang tibia meliputi proses pemadatan dan penyusunan matrik tulang, bagian permukaan epifisi dan diafisis seiring perkembangannya akan mengalami klasifikasi secara terus menerus sampai pertumbuhan memanjang dari kerangka terhenti, kalsifikasi tulang merupakan proses pengendapan mineral terutama kalsium dan fosfor kedalam matriks tulang (Tillman et al., 2015). Dalam pertumbuhan tulang tibia dibutuhkan Ca dan $\mathrm{P}$ yang seimbang, apabila tidak seimbang maka akan terjadi pelepasan Ca dari tulang melalui reabsorpsi tulang. Proses ini akan mengorbankan $\mathrm{Ca}$ dari tulang guna menyeimbangkan konsentrasi Ca dalam darah, sehingga berpengaruh terhadap pertumbuhan dan kandungan Ca dalam tulang.

Kalisium (Ca merupakan salahsatu mineral esensial terbanyak dalam tubuh, lebih dari 90\% kalsium dalam tubuh terdapat dalam tulang. (Waldroup, 1997). Kalsium (Ca) dan fosfor $(\mathrm{P})$ berfungsi untuk pertumbuhan tulang, pembentukan kerabang, membentuk rangka yang kuat, melindungi organ yang penting. Kekurangan kalsium dan fosfor yang dikonsumsi dapat menyebabkan terjadinya mobilisasi kalsium dan fosfor dari tulang sehingga bobot tulang akan berkurang dan keropos (Bangun et al., 2013).

Peningkatan pertumbuhan panjang tulang tibia yang memiliki sifat fisiologi yaitu mempunyai korelasi sekitar 90\% - 95\% dan meniralisasi lebih tinggi daripada tulang femur dibutuhkan nutrisi yang mendukung tidak kalah penting adalah protein yang tinggi untuk menunjang minaralisasi tulang tibia. Untuk dapat memaksimalkan panjang tulang tibia dibutuhkan program 1L : 3D artinya tulang tibia membutuhkan korelasi bobot badan dengan panjang tulang tibia dan untuk memaksimalkan mineralisasi atau klasifikasi kalsium dan fosfor pada tulang tibia dengan bantuan.

Hasil penelitian terhadap panjang tulang metatarsus diketahui bahwa pertumbuhan tulang metatarsus tertinggi terdapat pada pada perlakuan 3 yaitu P2 dengan hasil rataan perlakuan 6,1 yaitu pada Ransum komersial $+10 \%$ silase limbah ikan dan pertumbuhan tulang metatarsus paling rendah terjadi pada pada perlakuan 2 yaitu P1 dengan hasil rataan perlakuan $5,85 \mathrm{~cm}$ yaitu pada ransum komersial $+5 \%$ silase limbah ikan berdasarkan perhitungan sidik ragam ketiga perlakuan terhadap panjang tulang metatarsus diketahui bahwa tidak berbeda nyata $>0,05 \%$ yang menyatakan bahwa Ho diterima yaitu tidak ada efektivitas ketiga perlakuan terhadap panjang tulang metatarsus.

Faktor penyebab tidak adanya efektivitas ketiga perlakuan terhadap panjang tulang metatarsus perlakuan hampir sama dengan panjang tulang metatarsus tanpa perlakuan. Efektifitas juga bisa tidak tercapai apabila perlakuan tidak akan tercapai apabila perlakuan yang diberikan tidak optimal, perlakuan pencahayaan hanya dilakukan 12 jam yaitu dari pukul 18.00-06.00 padahal di siang hari bebek terpapar sinar matahari (protoperiod). Ransum yang berpengaruh terhadap nutrisi yang dibutuhkan pada bebek berpengaruh terhadap hormonal bebek, pernyataan tersebut didukung penelitian-penelitian sebelumnya yaitu menurut Rose (1997), faktor-faktor yang mempengaruhi pertumbuhan tulang meliputi faktor endogenous (faktor yang dipengaruhi oleh hormone) dan exogeneous (faktor yang dipengaruhi oleh pakan) yang meliputi faktor nutrisi yaitu, protein vitamin, mineral dan kalsium.

Tulang metatarsus merupakan tulang kering sebagai tempat deposisi mineral kalsium dan fosfor paling banyak yang digunakan untuk pembentukan kerangka tulang dibandingkan dengan tulang panjang lainnya. Tulang metatarsus memiliki pertumbuhan yang lebih lambat dibandingkan dengan pertumbuhan tulang kaki lainnya seperti tulang femur dan tibia (Candrawati, 2007; Bangun et al., 2013). Fisiologi tulang metatarsus juga 
diperkuat dengan penelitian sebelumnya yaitu dapat diketahui juga bahwa panjang tulang metatarsus pada bebek memiliki korelasi dengan bobot badannya, sehingga pertumbuhan tulang metatarsus juga semakin cepat untuk menompang berat tubuh bebek (Kurniawan; Atmomarsono; Mahfudz, 2012).

\section{SIMPULAN}

Berdasarkan hasil dan pembahasan dapat disimpulkan bahwa peningkatan kualitas bebek pedaging terhadap panjang tulang dengan penambahan silase limbah ikan yaitu tidak adanya pengaruh terhadap panjang tulang (femur, tibia dan metatarsus) $(\mathrm{P}>0,05)$, pada bebek pedaging.

\section{DAFTAR PUSTAKA}

Abun, 2004. Pengaruh Cara Pengolahan Limbah Ikan Tuna Terhadap Kandungan Gizi dan Nilai Energi Metabolisme Pada Ayam Pedaging. Laporan Penelitian. Unpad. Bandung.

Bangun, G. D. D., L. D. Mahfudz dan D. Sunarti. 2013. Pengaruh penggunaan tepung rumput laut (Gracilaria verrucosa) dalam ransum ayam broiler terhadap berat ukuran tulang tibia dan tarsometatarsus. J. Anim Agric. 2 (1) : 489 - 496.

Bevelander, G. and J.A. Ramaley. 1974. Essentials of Histology. 7thed. The C.V.

Candrawati, V. Y. 2007. Studi Ukuran dan Bentuk Tubuh Ayam Kampung, Ayam Sentul dan Ayam Wareng Tangerang. Fakultas Peternakan Institut Pertanian Bogor, Bogor. (Skripsi Sarjana Peternakan).

Hastuti, D. T., Mahfudz, L. D., dan Sarengat, D. W. 2013. Pengaruh penggunaan tepung buah jambu biji merah dalam ransum terhadap pertumbuhan tulang ayam broiler. Animal Agricultural Journal 2(2): 26-32.

Kurniawan, L. A., U. Atmomarsono dan L. D. Mahfudz. 2012. Pengaruh berbagai frekuensi pemberian pakan dan pembatasan pakan terhadap pertumbuhan tulang ayam broiler. Jurnal Agromedia. 30 (2) : $14-22$.

Masrianto, Fakhrurrazi, dan Azhari. 2013. Uji Residu Antibiotik pada Daging Sapi yang dipasarkan di Pasar Tradisional Kota Banda Aceh. Jurnal Medika Veterinaria, 7(1):13-14.

Rizkuna, A., U. Atmomarsono dan D. Sunarti. 2014. Evaluasi pertumbuhan tulang ayam kampung umur 0-6 minggu dengan taraf protein dan suplementasi lisin dalam ransum. J. Ilmiah dan Teknologi Peternakan. 3 (3): 121-125.

Rose, S. P. 1997. Principle of Poultry Science. Centre for Agricultura and Bioscience International, New Cork.

Sartika, T. 2000. Studi Keragaman Fenotipik dan Genetik Ayam KUB (Gallus Gallus Domesticus) pada Populasi Dasar Seleksi. Tesis. Bogor: Institut Pertanian Bogor.

Setiawan. 2016 Complete feed batang pisang terfermentasi dengan level protein berbeda terhadap kecernaan bahan kering,kecernaan bahan organik dan TDN secara in vitro. Jurnal Ilmu-Ilmu Peternakan. 26 (2): 67-72.

Tillman, A. D., Hartadi, S. Reksodiprodjo, D. Prwawirokusomo dan S. Lebdosoekojo. 1989. Ilmu Makanan Ternak Dasar. Yogyakarta: UGM Press.

Wahju, J. 2004. Ilmu Nutrisi Unggas. Cetakan ke-6. Gadjah Mada University Press, Yogjakarta.

Waldroup, P.W.1997. Particle Size Reduction of Cereal Grains and its Significance in Poultry Nutrition. Technical Bulletin PO34-1997, American Soybean Association, Singapore. $14 \mathrm{pp}$.

Wilson, H. R, M. A. Boone, A. S. Arofa and D. M. Janky. 1991. Abdominal Fat Padreduction in Broiler With Thyroactive Iodinated Casein. Poultry Sci. 62: 811818. 